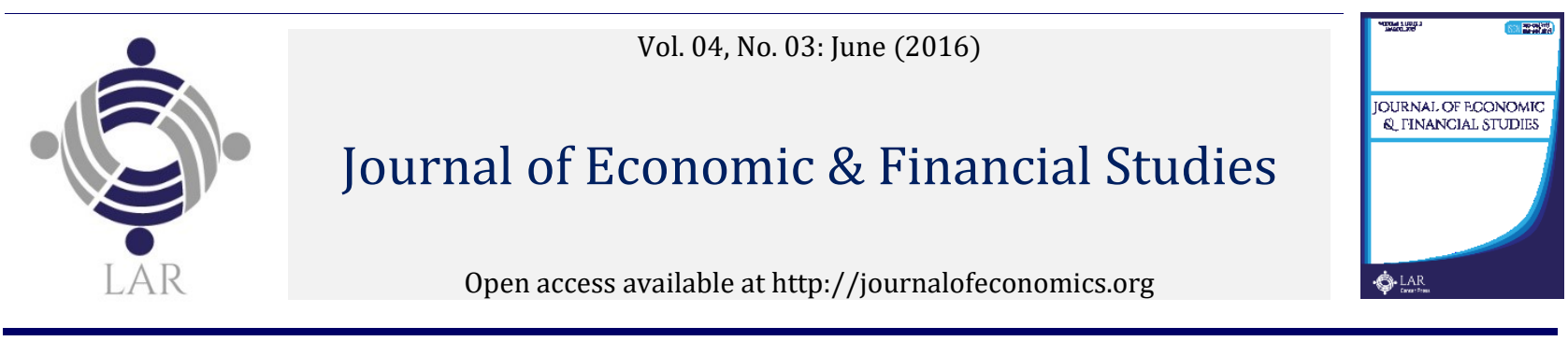

\title{
Banking access for the poor: Adoption and strategies in rural areas of Bangladesh
}

\author{
Mohammad Anisur Rahman a* Xu Qi ${ }^{\mathrm{b}}$, Md. Tariqul Islam ${ }^{\mathrm{b}}$ \\ a Department of Logistics Management and e-Commerce, Glorious Sun School of Business and Management \\ Donghua University, Shanghai, China. \\ a Department of Management Information Systems, University of Dhaka, Bangladesh. \\ b Department of Logistics Management and e-Commerce, Glorious Sun School of Business and Management, Donghua University, \\ Shanghai, China. E-mail: xuqi@dhu.edu.cn \\ c Department of Business Administration, BGMEA University of Fashion \& Technology(BUFT), Dhaka, Bangladesh. E-mail: \\ tareq.islam.du@gmail.com \\ *Corresponding author's email address: anisur@du.ac.bd
}

\section{A R T I C L E I N F O}

Received: 15-05-2016

Accepted: 25-06-2016

Available online: 28-06-2016

\section{Keywords:}

Adoption; Bangladesh;

Mobile banking; Rural;

Strategies.

JEL Classification : G29, L86

\begin{abstract}
A B S T R A C T
The progress of Mobile Banking (M-banking) is unsatisfactory in terms of achieving a key objective, i.e. to reach the inaccessible unbanked customers at an affordable cost for financial inclusion. We identify the causes to this problem through the investigating the factors affecting the adoption of m-banking in remote areas of Bangladesh using a 236 primary sample of m-bank customers from seven geographical locations and across professions. We document a positive effect of perceived ease of use, trusts, and perceived usefulness, and a negative effect of user interface on adopting m-banking in rural Bangladesh. our findings provides significant policy implications for policy planners and the bank managers to enrich their policies and strategies for promoting financial inclusion as well as successful banking business in rural of Bangladesh.
\end{abstract}

(C) 2016 The Authors. This is an open access article under the terms of the Creative Commons Attribution License 4.0, which allows use, distribution and reproduction in any medium, provided the original work is properly cited.

\subsection{Introduction}

Financial inclusion (FI) and development are closely related. Sarma and Pais (2011) defined financial inclusion as a process that ensures availability, the ease of access, and usage of the formal financial system for all members of an economy. It facilitates efficient allocation of resources and financial management; increasing formal savings and credits; reduction of poverty and improving equality (Chibba, 2009; Sarma \& Pais, 2011). Different countries especially lower and the middle-income group set FI as their policy priority to achieve SDGs by capitalizing the use of ICT to embrace the marginal people financially.

Mobile phone, a blessing of ICT, has shown promising outcome in both economic empowerment and social development in different countries (Rashid \& Elder, 2009). Citizen around the world can access information related to health, education, weather, news, jobs, finance and market through mobile phones. People in developing countries are enjoying financial systems, government services, and citizen feedback mechanisms with the increased mobile penetration (Canuto, 2013). These economic and social benefits of a cell phone, however, evidently found to be the highest in rural areas (Sarma and Pais 2011), where the marginal, hard to reach and unbanked people live. These people have access to mobile but financially excluded, which is evident from the world development indicators. 
The World Bank data (2014) shows that in the high-income group countries $73 \%$ of the population (age 15+) has bank account, and $126 \%$ of the population (age 15+) has mobile phone subscription; whereas in low to middle income countries about $53 \%$ of the population (age 15+) has bank account while $90 \%$ of the population (age $15+$ ) has mobile access. In Bangladesh, $29 \%$ of the population (age 15+) has a bank account while $76 \%$ of the population (age 15+) has mobile access. The data reveals that people in the high-income group have higher banking and mobile access than that of lower and middle-income nations. Mobile banking is one of the best ways to reach these unbanked population for financial inclusion.

The term mobile banking simply means the banking services delivered and received using cell phones. The adoption of ICT in the banking and financial sector opened this new, innovative and affordable channel of delivering banking and financial services. Mobile banking, is using same technology like e-banking (Welch, 1999), enabled the banking industry to perform fastest wireless and Internet commercial transactions (Greenacre \& Buckley, 2014). However, the core advantage of mobile banking is that banks can serve its customers even where the internet is absent and with minimum technological knowledge of customers. As a result, the modern means of sitting in front of computers for getting any services is no more required to obtain the defined services (Ahmed, Rayhan, Islam, \& Mahjabin, 2012).

Taking the advantage of the mobility (Suoranta, 2003) and internet independent technology, mobile banking in different countries were launched to access the unbanked population for financial inclusion (Nabi et al., 2012). The assumption behind the financial inclusion of the unbanked population is facilitating them to access the economic benefits, such as increased savings, credits, increased income and protection from financial shocks (Donner \& Tellez, 2008). The government can reap the benefits of increased capital from the untapped portion of the population, transparency in the transactions, increased tax potentiality and greater circulation of money that were currently not in the account. For example, M-Pesa, mobile banking service in Kenya is a blockbuster success story for the world. It was introduced in 2007 to make and receive payments. The household that adopted M-Pesa seemed to have increased in income by $5-30 \%$ (The Economist, 2013). Through mobile banking, the Kenya have been able to drop its financially excluded population to 3\% (The Daily Prothom Alo, 2015). M-Pesa today operates in 10 countries. M-Pesa, the mobile banking model, has been replicated in other parts of the world including Bangladesh.

Mobile banking in Bangladesh, started in the year 2011, is playing a significant role in the rural economy of Bangladesh. The most popular services they enjoy from mobile banking are deposit and withdrawal of money, payment of gas, electricity and water bill. According to Bangladesh Bank (till May 2016), 29 banks are authorized for providing mobile banking services, of which 19 have already started their functions; about Tk. 6.2 billion transacted daily over mobile banking platform through 592 thousand agents.

However, the effect of mobile banking on the financial inclusion of the poorest $40 \%$ of the adult population, who reside in the rural areas in Bangladesh, is scanty. In the year 2011, while the mobile banking was introduced, the financial inclusion of the poorest $40 \%$ adult in Bangladesh was $21.2 \%$ and in the year 2014, that grew to $21.5 \%$ (The World Bank, 2014a). Clearly, the policy makers both the government and the banks are missing something, which is deterring the poorest $40 \%$ of the adult population to adopt mobile banking although they are the subscribers of cell phones.

Till date, most of the research on mobile banking adoption (Aderonke, 2010; Akturan \& Tezcan, 2012; Al-Jabri \& Sohail, 2012; AlSoufi \& Ali, 2014; Crabbe, Standing, Standing, \& Karjaluoto, 2009; DiVanna, 2003; Goi, 2006; Gu, Lee, \& Suh, 2009; Haig, 2002; Hanafizadeh, Behboudi, Abedini Koshksaray, \& Jalilvand Shirkhani Tabar, 2014; Hassan, Rahman, Afrin, \& Rabbany, 2014; Kabir, 2013; Karjaluoto, Koenig-Lewis, Palmer, \& Moll, 2010; Karjaluoto, Riquelme, \& Rios, 2010; Kazi \& Mannan, 2013; Khraim, Al Shoubaki, \& Khraim, 2011; Laforet \& Li, 2005; Lee, Lee, \& Kim, 2015; Luarn \& Lin, 2005; Mattila, 2003; Mbiti \& Weil, 2011; Medhi, Ratan, \& Toyama, 2009; Nayak, Nath, \& Goel; Oshunloye, 2009; Suoranta, 2003; Yu, 2012; Zhou, Lu, \& Wang, 2010) either focus on developed countries or on developing countries from a narrow or urban scope. Most of the previous research is lagging behind in identifying the factors contributing to the adoption of mobile banking in rural areas. Reaching the unbanked inaccessible population of the countryside remain a challenge for any developing as well as developed nations. This study tried to fill this research gap by identifying the determinants of mobile banking adoption in rural areas.

\section{$2.0 \quad$ Literature review}

Mobile banking has given the opportunity to the customer to perform banking operations irrespective of time, place and the Internet (Chitungo \& Munongo, 2013; Suoranta, 2003). It has opened the possibility of financial inclusion of millions of people remotely located and unbanked to share the economic development. However, 
compared to the overall banking transactions, the market for mobile has remained subtle in Bangladesh. It seems that the widespread adoption of cell phones does not reflect the high level of mobile banking adoption(Yu, 2012). Customers of Iran, Guatemala and Mexico, can obtain banking services through the local mobile network. Pakistan has also launched mobile banking services with limited facilities, but India provides services in wider areas. The scenario in China, Brazil and Kenya is quite different regarding the number of users. Here the number of users soared over $100 \%$. In UK, USA, Singapore, South Korea and Sweden, banks provide new services to their customers via mobile handset (Khraim, et al., 2011).

In 2011, Zimbabwe started mobile banking services which were the panacea for the unbanked rural areas of the country. Now it has become the most popular financial channel for all in Zimbabwe (Aboelmaged \& Gebba, 2013). Applications of mobile banking in Bahrain has been growing up rapidly and expected to increase in the coming year; most of the banks of Bahrain now operate mobile banking due to the popularity of this service (AlSoufi \& Ali, 2014). However, the economy where banking access is comparatively higher, adoption of mobile banking seems to lower (Cudjoe, Anim, \& Nyanyofio, 2015).

Direct marketing of mobile banking is very crucial for the penetration of mobile banking on a grand scale. The service providers sometimes think that promotion of mobile banking may occur within the branch, but the scenario has changed (Bankole, Bankole, \& Brown, 2011). Customer's recognition or understanding of the potential value of mobile banking is very urgent for increasing the number of users. Creating awareness for the value of mobile banking can be a useful tool for this purpose (Nayak et al.).

Medhi et al. (2009) undertook a qualitative study in four countries (India, Kenya, Philippines and South Africa) on 90 respondents to identify the barriers to mobile banking adoption. They found that household type, services, usage frequency, ease of use and uptake deter the use of mobile banking adoption of the financially excluded group. On the contrary, Kazi and Mannan (2013) identified innovative promotional and pricing strategies should adopt by the service providers to increase the number of acceptance. Findings of the researchers on the mobile banking adoption have been summarized in Table 1.

Table 1: Determinants of mobile banking adoption identified in different research / countries

Researchers
Suoranta (2003)
Laforet and Li (2005)
Crabbe et al. (2009)
Medhi et al. (2009)

Karjaluoto, Koenig-Lewis, et al. (2010)

Bankole et al. (2011)

Khraim et al. (2011)

Al-Jabri and Sohail (2012)

Akturan and Tezcan (2012)

Kazi and Mannan (2013) Aboelmaged and Gebba (2013)

Kabir (2013)

Chitungo and Munongo (2013)

AlSoufi and Ali (2014)

Ndumba and Muturi (2014)

\section{Determinants Identified}

relative advantage, compatibility,

communication and trialability

security, perception of risks, technological skills, and awareness

perceived credibility, facilitating conditions, perceived elitisation, and demographic factors

household type, key

service adopted pace of uptake, frequency of usage, and ease of use.

compatibility, perceived usefulness, and risk

culture, utility expectancy, effort expectancy, and behavioral intention

self-efficacy, trialability, compatibility, complexity, risk and relative advantage

relative advantage, compatibility, received risk and observability

attitude, perceived usefulness, perceived social risk, Turkey

perceived performance risk and perceived benefit

perceived risk, ease of use, usefulness and social influence

Attitude, subjective norm, perceived ease of use and perceived usefulness

perceived risks (except social

risk), trust, convenience, and comparative advantages

perceived ease of use, relative advantages, social norms, personal innovativeness, perceived risks, perceived usefulness, and costs

perceived Usefulness and Ease of Use

perceived risk, perceived convenience, perceived usefulness and trust
Location / Context

Finland

China

Ghana

India, Kenya,

Philippines and South Africa (rural / poor)

Germany

Nigeria

Jordan

Saudi Arabia

Pakistan

Dubai

Bangladesh

Zimbabwe

Bahrain

Kenya 
Table 1: Determinants of mobile banking adoption identified in different research / countries

\begin{tabular}{|c|c|c|}
\hline Researchers & Determinants Identified & Location / Context \\
\hline $\begin{array}{l}\text { Blumenstock, Callen, and } \\
\text { Ghani (2014) }\end{array}$ & violence, intention & Afghanistan \\
\hline (Nayak, Nath, \& Goel, 2014) & awareness, perceived usefulness, perceived ease of use, trust & India \\
\hline K. S. Lee et al. (2015) & perceived risk, trust, and perceived usefulness & South Korea \\
\hline (Cudjoe et al., 2015) & $\begin{array}{l}\text { perceived credibility, perceived financial cost, perceived } \\
\text { usefulness and perceived ease of use }\end{array}$ & Ghana \\
\hline
\end{tabular}

\subsection{Theoretical framework and hypotheses development}

Our study aimed at finding out the determinants of mobile banking adoption by the rural people. Previously, researchers have used many models available to identify the adoption of new technology; such as the technology acceptance model (Davis, Bagozzi, \& Warshaw, 1989), the Unified Theory of Acceptance and Use of Technology (Venkatesh, Thong, Chan, Hu, \& Brown, 2011), Theory of Planned Behavior (Venkatesh et al., 2011), Theory of Reasoned Action (Albarracin, Johnson, Fishbein, \& Muellerleile, 2001), and the Innovation Diffusion Theory (Moore \& Benbasat, 1996), etc. Among these, Technology acceptance model (TAM) is the most dominant model used for the study of the adoption of information technology and thus TAM has been used for this study. The theoretical framework has been shown in Figure 1.

\subsection{Perceived ease of use and m-banking adoption}

Perceived ease of use has significant influences on technology adoption (Iqbal \& Bhatti, 2015). In mobile banking, it means a degree to which a person is free of difficulty with the usage of mobile banking technology (Aderonke, 2010). The relationship between perceived ease of use and mobile banking efficacy is positive because it indicates the hands on experience of the users (Luo, Li, Zhang, \& Shim, 2010). We hypothesized that:

H1: PEU has significant positive influences on mobile banking adoption.

\subsection{User interface and m-banking adoption}

The user interface requires an in-depth understanding of user need (Thakur \& Srivastava, 2014). The best interface is that a user will have all types of access regarding usability and understanding. It enhances the relationship between users and the system (Ha, Canedoli, Baur, \& Bick, 2012). So we hypothesized that:

H2: User interface has positive influences on mobile banking adoption.

\subsection{Trust and m-banking adoption}

When the user chooses a particular system, (s)he must consider the overall trust on that technology (Slade, Williams, \& Dwivedi, 2013). Trust on using a technology fosters the adoption of technology (Lee, Kim, \& Ahn, 2011) and the degree of confidence heading towards the adoption of new technology (Shareef, Kumar, Kumar, \& Dwivedi, 2011). Based on above discussion, we hypothesized that:

H3: Trust has positive influences on mobile banking adoption.

\subsection{Perceived usefulness and m-banking adoption}

Perceived usefulness is a critical construct in our proposed model which means that to what extent the person believes that using the technology will enhance his/ her performance (Hoque, Bao, \& Sorwar, 2016). In mobile banking, it means obtaining services as desired by the user (Karjaluoto, Koenig-Lewis, et al., 2010). Accordingly, we hypothesized that:

H4: Perceived usefulness has positive influences on mobile banking adoption.

\subsection{Research design and methods}

\subsection{Research setting}

Due to the limited research on the adoption of mobile banking in rural areas of Bangladesh, we undertook an exploratory research in rural parts of Bangladesh with a structured questionnaire. Sample frame included Gazipur (40), Tongi (30), Norsingdi (25), Faedabad (33), Savar (35), Narayanganj (42) and Comilla (31) regions of Bangladesh. Due to the cost effectiveness, a convenience sampling method was used. The participants were informed about the purpose of the study. 


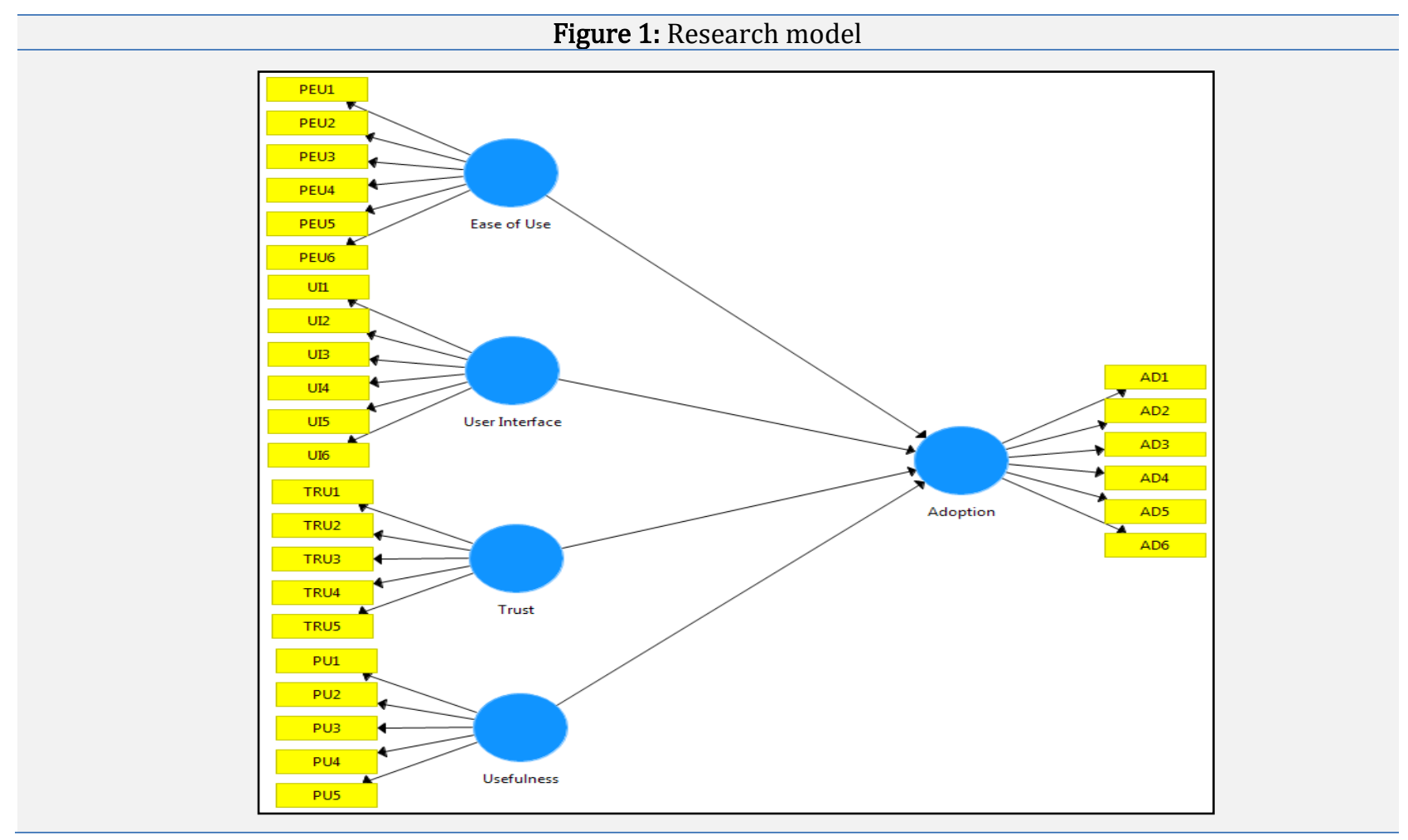

\subsection{Questionnaire design and data collection}

To collect the relevant data for measuring the latent constructs in the research hypotheses, we adopt the structured questionnaire survey method. There were two parts in the questionnaire. Part A contains the demographic information that was used to have the descriptive characteristics of the sample.

In part B, there were some questions regarding the different constructs in the research model on a 5 point Likert scale. A face-to-face meeting was conducted to obtain the response of the participants for this study. We distributed 300 questionnaires, and 243 were returned. We used 236 questionnaires for further analysis, and seven incomplete questionnaires were excluded from the survey. We used statistical analysis technique, based on structural equation modeling (SEM) called the partial least squares (PLS) method to test and validate the proposed model and the relationships among the hypothesized constructs. Smart PLS 3.0 (Ringle, Wende, \& Becker, 2015) software has been used to analyze the data.

\subsection{Findings}

\subsection{Measurement model evaluation}

The measurement model has been assessed through the internal reliability, convergent validity, and discriminant validity. The internal reliability was examined through the Cronbach's alpha and Composite Reliability (CR). For both of the measurement, the constructs had more than recommended value, i.e., greater than 0.7. So all the constructs or latent variables used in this study were found reliable. The average variance extracted (AVE) and item loading for all the elements or observed variables are above the threshold value of 0.50 . The items used in this study thus have the convergent validity. Table 2 shows the Measurement model results.

The discriminant validity has been assessed by the square root of the AVE and crosses loading matrix. For discriminant validity, the diagonal elements must be larger than the entries in corresponding columns and rows.

From the results of Table 3, it can be seen that all the diagonal values are greater than the values of corresponding columns and rows, indicating the discriminant validity of the constructs.

\begin{tabular}{lrrrrr}
\hline & \multicolumn{5}{c}{ Table 2: The measurement model } \\
Constructs & Items & Loadings & C.R & Cronbach's Alpha & AVE \\
\hline & AD1 & 0.845 & & & \\
Adoption & AD2 & 0.853 & 0.94 & 0.92 & 0.71 \\
\hline
\end{tabular}




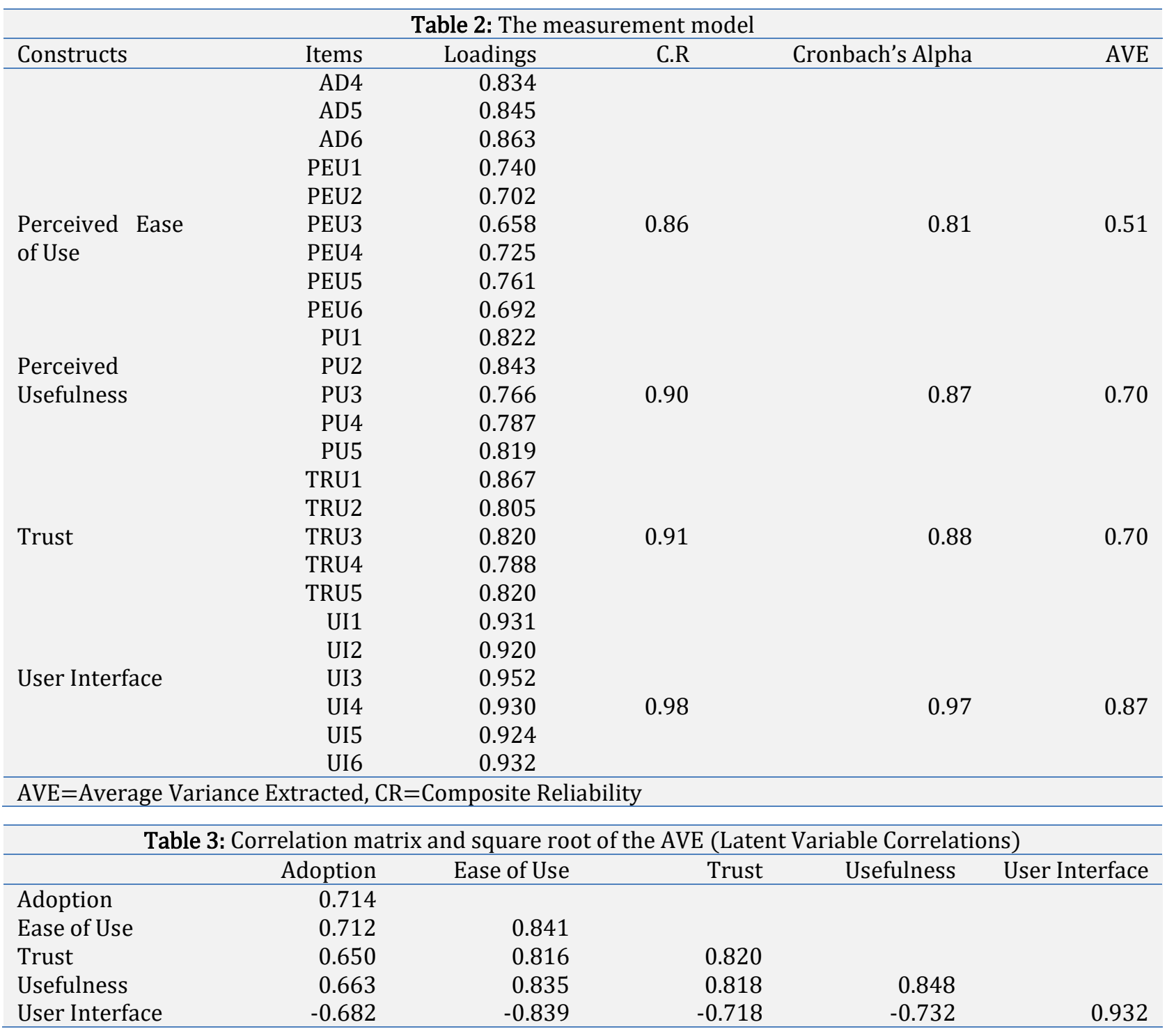

\section{$5.2 \quad$ Hypotheses Testing}

To identify the relationships among the constructs in the research model, we develop the structural model. By the path coefficient $(\beta)$ and t-statistics, we evaluate the relationship between dependent and independent variables. Table 4 shows the PLS results of the structural model for this study. The results indicate the relationships between PEU and AD $(t=2.813, \beta=0.111, p<0.05)$, UI and AD $(t=7.999, \beta=-0.403, p<0.05)$, TRU and AD $(t=3.790$, $\beta=0.206, p<0.05)$, PU and AD $(t=4.673, \beta=0.290, p<0.05)$. So H1, H2, H3, and H4 were significant and accepted in the current study. Overall the constructs in this model explain about $83 \%$ of the variations in the adoption of mobile banking, which is greater than recommended level of $20-25 \%$.

\begin{tabular}{lrrrrr}
\hline & \multicolumn{5}{c}{ Table 4: Structural model } \\
\hline Hypothesis & Path & $(\beta)$ & t-statistics & Comments & $\mathrm{R}^{2}$ \\
\hline H1 & PEU - > AD & 0.111 & 2.813 & Accepted & 0.828 \\
H2 & UI - - AD & -0.403 & 7.999 & Accepted & \\
H3 & TRU - > AD & 0.206 & 3.790 & Accepted & \\
H4 & PU - > AD & 0.290 & 4.673 & Accepted & \\
\hline
\end{tabular}

\subsection{Discussion}

We tried to identify the factors determining the adoption of mobile banking in rural Bangladesh using TAM model. Through analyzing the survey data of 236 respondents, we found that all the constructs have a strong relationship with the adoption of mobile banking. The results revealed the significant influences of PEU, UI, TRU and PU on the adoption of mobile banking. 
The unique finding of this study is the User Interface, which is exceptional from the results of the previous studies (see Table 1). UI seems to work as a deterrent for the adoption of mobile banking in Bangladesh. The plausible cause may the language used in mobile banking. The language in the mobile banking is English, which is not understood by many rural users. Using the Bengali language might help here. Akturan and Tezcan (2012) has found that the user interface is more crucial when users have the lacking of experience in using technology. The rural adults are using mobile technology, which is relatively new to this section of the population. Using this technology for money transaction might make them nervous. We believe the use of local language and more experience over time will help the users to overcome UI related nervousness.

The second most influencing factor is the Perceived Usefulness (PU); which confirms most of the previous findings (see Table 1). Currently, the users of mobile banking are mostly using money transfer facility of the mobile banking services. Because a large number of people such as garments workers, factory workers, and rickshaw pullers are working remotely from their home. They constantly need to send money to their family members back at home safely. Mobile banking has become a safe tool for them to send and receive money. However, the transaction is mainly done through agents rather than opening an own mobile banking account. After PU, the user needs to trust the mobile banking system to adopt it.

Like the previous research (Kabir 2013, Ndumba and Muturi 2014, Lee et al. 2015; Nayak et al., 2014, Wu and Wang 2005), our research also found trust as an influencing factor for adoption of mobile banking. Mobile banking is more sensitive unlike any other technology because it relates to the money.

Lastly, Perceived Ease of Use (PEU) found to be a statistically significant factor for mobile banking adoption like previous studies (see Table 1). Complex and hard to use issues increase the barrier to learning new technology. For the rural people, this factor is more crucial because their exposure to new technology and their educational level do not allow them to accept new technology as easily as the rich group. For this reason, in Bangladesh the popular mobile banking service providers such as BKash, DBBL uses push and pull services which are easy to use and work even in feature phones.

\subsection{Conclusion and implications}

Financial inclusion is one of the vital indicators of development. It also indicates the financial strength of a nation. Mobile banking in different parts of the world found to be an effective tool to embrace financially the marginal people who do not have any banking access.

Mobile banking introduced in Bangladesh for about six years. However, its effect on the financial inclusion is found to be ineffective unlike other parts of the world. Our research tried to find the answer for this situation by identifying the determinants of mobile banking adoption by the rural people of Bangladesh.

We discovered that user interface (UI), perceived ease of use (PEU), trust, and perceived usefulness (PU) are statistically significant factor for the adoption of mobile banking in the rural parts of Bangladesh. However, the user interface has significant negative impact on the mobile banking adoption.

\subsection{Theoretical Implications}

This study contributes to IS research by providing a conceptual framework for using and accepting mobile banking in rural areas. Our study uniquely identified the user interface as the major influencing factor for mobile banking adoption by the marginal people. The research is conducted in only some specific rural areas of Bangladesh, so the results may not provide an accurate reflection towards the adoption of mobile banking in Bangladesh. A potential future research might be to focus on the wider areas of Bangladesh to identify and include some other possible factors for making a more widely applicable model.

\subsection{Managerial implications}

The managers of the mobile banking operations may use this finding to design their products and services more customer friendly and technologically superior for the adoption by the marginal rural population. They should especially concentrate on the user interface and perceived usefulness. Managers can design the push-pull services in local Bengali language so that the rural people can understand. Introduction of interactive voice response (IVR) service in addition to push-pull message interface may help the less educated and senior citizen to use the system. The more benefits relating to product and services the managers can offer, the more they can penetrate the market. 


\subsection{Policy implications for government}

Policy makers as such the government should introduce different services that motivate the marginal people to adopt mobile banking to accelerate the adoption rate. For example, the government can disburse social security benefits and receive payment of tax, tariff, fees through personal mobile banking account. In this way, people can be benefited by micros savings, interest income, micro-credits, and payments; that will result in an equitable share of development.

\section{References}

Aboelmaged, M., \& Gebba, T. R. (2013). Mobile banking adoption: an examination of technology acceptance model and theory of planned behavior. International Journal of Business Research and Development (IJBRD), 2(1).

Aderonke, A. A. (2010). An empirical investigation of the level of users' acceptance of e-banking in Nigeria. Journal of Internet Banking and Commerce, 15(1), 1.

Ahmed, S. S., Rayhan, S. J., Islam, A., \& Mahjabin, S. (2012). Problems and prospects of mobile banking in Bangladesh. Researchers World, 3(1), 47.

Akturan, U., \& Tezcan, N. (2012). Mobile banking adoption of the youth market: Perceptions and intentions. Marketing Intelligence \& Planning, 30(4), 444-459.

Al-Jabri, I. M., \& Sohail, M. S. (2012). Mobile Banking Adoption: Application Of Diffusion Of Innovation Theory. Journal of Electronic Commerce Research 13(4), 379-391.

Albarracin, D., Johnson, B. T., e Fishbein, M., \& Muellerleile, P. A. (2001). Theories of reasoned action and planned behavior as models of condom use: a meta-analysis. Psychological bulletin, 127(1), 142.

AlSoufi, A., \& Ali, H. (2014). Customers perception of mbanking adoption in Kingdom of Bahrain: an empirical assessment of an extended tam model. arXiv preprint arXiv:1403.2828.

Bank, T. B. (2016). Mobile Financial Services (MFS) Data. Mobile Financial Services (MFS) comparative summary statement of April, 2016 and May, 2016. Retrieved 29 June 2016, 2016, from https://www.bb.org.bd/fnansys/paymentsys/mfsdata.php

Bankole, F. O., Bankole, O. 0., \& Brown, I. (2011). Mobile banking adoption in Nigeria. The Electronic Journal of Information Systems in Developing Countries, 47.

Blumenstock, J., Callen, M., \& Ghani, T. (2014). Violence and Financial Decisions: Evidence from Mobile Money in Afghanistan. University of Washington.

Canuto, O. (2013). Mobilizing Development via Mobile Phones. Growth and Crisis. Retrieved 27 June 2016, 2016, from http://blogs.worldbank.org/growth/mobilizing-development-mobile-phones

Chibba, M. (2009). Financial Inclusion, Poverty Reduction and the Millennium Development Goals. The European Journal of Development Research, 21(2), 213-230. doi: 10.1057/ejdr.2008.17

Chitungo, S. K., \& Munongo, S. (2013). Extending the technology acceptance model to mobile banking adoption in rural Zimbabwe. Journal of Business Administration and Education, 3(1), 51.

Crabbe, M., Standing, C., Standing, S., \& Karjaluoto, H. (2009). An adoption model for mobile banking in Ghana. International Journal of Mobile Communications, 7(5), 515-543.

Cudjoe, A. G., Anim, P. A., \& Nyanyofio, J. G. N. T. (2015). Determinants of mobile banking adoption in the Ghanaian banking industry: a case of access bank Ghana limited. Journal of Computer and Communications, 3(02), 1.

Davis, F. D., Bagozzi, R. P., \& Warshaw, P. R. (1989). User acceptance of computer technology: a comparison of two theoretical models. Management science, 35(8), 982-1003.

DiVanna, J. A. (2003). The future of retail banking. Springer.

Donner, J., \& Tellez, C. A. (2008). Mobile banking and economic development: Linking adoption, impact, and use Asian journal of communication, 18(4), 318-332.

Goi, C. L. (2006). Factors influence development of e-banking in Malaysia. Journal of Internet Banking and Commerce, 11(2), 1-21.

Greenacre, J., \& Buckley, R. P. (2014). Using trusts to protect mobile money customers. Sing. J. Legal Stud., 59.

Gu, J.-C., Lee, S.-C., \& Suh, Y.-H. (2009). Determinants of behavioral intention to mobile banking. Expert Systems with Applications, 36(9), 11605-11616. doi: 10.1016/j.eswa.2009.03.024

Ha, K.-H., Canedoli, A., Baur, A. W., \& Bick, M. (2012). Mobile banking-insights on its increasing relevance and most common drivers of adoption. Electronic Markets, 22(4), 217-227.

Haig, M. (2002). Mobile marketing: The message revolution: Kogan Page Publishers.

Hanafizadeh, P., Behboudi, M., Abedini Koshksaray, A., \& Jalilvand Shirkhani Tabar, M. (2014). Mobile-banking adoption by Iranian bank clients. Telematics and Informatics, 31(1), 62-78. doi: 10.1016/j.tele.2012.11.001

Hassan, M. M., Rahman, A., Afrin, S., \& Rabbany, G. (2014). Factors Influencing the Adoption of Mobile Banking Services in Bangladesh: An Empirical Analysis. International Research Journal of Marketing, 2(1), 9. doi: 10.12966/irjm.02.02.2014 
Hoque, M. R., Bao, Y., \& Sorwar, G. (2016). Investigating factors influencing the adoption of e-Health in developing countries: A patient's perspective. Informatics for Health and Social Care, 1-17.

Iqbal, S., \& Bhatti, Z. A. (2015). An Investigation of University Student Readiness towards M-learning using Technology Acceptance Model. The International Review of Research in Open and Distributed Learning, 16(4).

Kabir, M. R. (2013). Factors influencing the usage of mobile banking: Incident from a developing country. World Review of Business Research, 3(3), 96-114.

Karjaluoto, H., Koenig-Lewis, N., Palmer, A., \& Moll, A. (2010). Predicting young consumers' take up of mobile banking services. International journal of bank marketing, 28(5), 410-432.

Karjaluoto, H., Riquelme, H. E., \& Rios, R. E. (2010). The moderating effect of gender in the adoption of mobile banking. International Journal of Bank Marketing, 28(5), 328-341.

Kazi, A. K., \& Mannan, M. A. (2013). Factors affecting adoption of mobile banking in Pakistan: Empirical Evidence. International Journal of Research in Business and Social Science, 2(3), 54.

Khraim, H. S., Al Shoubaki, Y. E., \& Khraim, A. S. (2011). Factors affecting Jordanian consumers' adoption of mobile banking services. International Journal of Business and Social Science, 2(20).

Laforet, S., \& Li, X. (2005). Consumers' attitudes towards online and mobile banking in China. International journal of bank marketing, 23(5), 362-380.

Lee, J., Kim, H. J., \& Ahn, M. J. (2011). The willingness of e-Government service adoption by business users: The role of offline service quality and trust in technology. Government Information Quarterly, 28(2), 222-230.

Lee, K. S., Lee, H. S., \& Kim, S. Y. (2015). Factors influencing the adoption behavior of mobile banking: a South Korean perspective , 2007. The Journal of Internet Banking and Commerce, 2007.

Luarn, P., \& Lin, H.-H. (2005). Toward an understanding of the behavioral intention to use mobile banking. Computers in Human Behavior, 21(6), 873-891. doi: 10.1016/j.chb.2004.03.003

Luo, X., Li, H., Zhang, J., \& Shim, J. (2010). Examining multi-dimensional trust and multi-faceted risk in initial acceptance of emerging technologies: An empirical study of mobile banking services. Decision support systems, 49(2), 222-234.

Mattila, M. (2003). Factors affecting the adoption of mobile banking services. Journal of Internet Banking and Commerce, 8(1), 0306-0304.

Mbiti, I., \& Weil, D. N. (2011). MOBILE BANKING: THE IMPACT OF M-PESA IN KENYA. NATIONAL BUREAU OF ECONOMIC RESEARCH. Retrieved from http://www.nber.org/papers/w17129

Medhi, I., Ratan, A., \& Toyama, K. (2009). Mobile-banking adoption and usage by low-literate, low-income users in the developing world. Paper presented at the International Conference on Internationalization, Design and Global Development Berlin Heidelberg.

Moore, G. C., \& Benbasat, I. (1996). Integrating diffusion of innovations and theory of reasoned action models to predict utilization of information technology by end-users Diffusion and adoption of information technology (pp. 132-146): Springer.

Nabi, M. G., Talukder, M. S., Saha, P. P., Sutradhar, R. R., Fahmida, A., Chen, G., \& Banerjee, B. (2012). Mobile Financial Services in Bangladesh: An Overview of Market Development. Bangladeh Bank Retrieved from https://www.bb.org.bd/pub/research/policypaper/pp072012.pdf.

Nayak, N., Nath, V., \& Goel, N. A Study Of Adoption Behaviour Of Mobile Banking Services By Indian Consumers.

Nayak, N., Nath, V., \& Goel, N. (2014). A Study Of Adoption Behaviour Of Mobile Banking Services By Indian Consumers. International Journal of Research in Engineering \& Technology, 2(3), 2347-4599

Ndumba, H. W., \& Muturi, W. (2014). Factors Affecting Adoption Of Mobile Banking In Kenya; Case Study Of Kenya Commercial Bank Limuru. International Journal of Social Sciences Management and Entrepreneurship, 1(3), 92-112.

Oshunloye, A. O. (2009). ICT in Marketing: A Study of The Use of Internet and Mobile Phones in. Journal of Business Venturing, 18(6), 789-814.

Rashid, A. T., \& Elder, L. (2009). Mobile phones and development: An analysis of IDRC-supported projects. The Electronic Journal of Information Systems in Developing Countries, 36(2), 1-6.

Ringle, C. M., Wende, S., \& Becker, J.-M. (2015). Bönningstedt: SmartPLS (Version 3.0). Retrieved from http://www.smartpls.com

Sarma, M., \& Pais, J. (2011). Financial Inclusion and Development. Journal of International Development, 23(5), 613-628. doi: 10.1002/jid.1698

Shareef, M. A., Kumar, V., Kumar, U., \& Dwivedi, Y. K. (2011). e-Government Adoption Model (GAM): Differing service maturity levels. Government Information Quarterly, 28(1), 17-35.

Slade, E. L., Williams, M. D., \& Dwivedi, Y. K. (2013). Mobile payment adoption: Classification and review of the extant literature. The Marketing Review, 13(2), 167-190.

Suoranta, M. (2003). Adoption of mobile banking in Finland. . Jyväskylän yliopisto.

Thakur, R., \& Srivastava, M. (2014). Adoption readiness, personal innovativeness, perceived risk and usage intention across customer groups for mobile payment services in India. Internet Research, 24(3), 369-392. 
The Daily Prothom Alo. (2015, 26 Aug 2015). Mobile banking is increasing financial inclusion, The Daily Prothom Alo. Retrieved from http://www.prothom-alo.com/economy/article/612703

The Economist. (2013). Why does Kenya lead the world in mobile money? Retrieved 27 June 2016, 2016, from http://www.economist.com/blogs/economist-explains/2013/05/economist-explains-18

The World Bank, World Development Indicator. (2014a). Account at Financial Institutions (\% age 15+). Retrieved 27 June 2016, from http://databank.worldbank.org/data/reports.aspx?source=2\&country=\&series=WP_time_01.3\&period=

The World Bank, World Development Indicator. (2014b). Mobile cellular subscriptions (per 100 people). $\begin{array}{llll}\text { Retrieved } 27 & \text { June } & \text { 2016, from }\end{array}$ http://databank.worldbank.org/data/reports.aspx?source=2\&country=\&series=WP_time_01.3\&period=

Venkatesh, V., Thong, J. Y., Chan, F. K., Hu, P. J. H., \& Brown, S. A. (2011). Extending the two-stage information systems continuance model: Incorporating UTAUT predictors and the role of context. Information Systems Journal, 21(6), 527-555.

Welch, B. (1999). Electronic banking and treasury security: Woodhead Publishing.

Wu, J.-H., \& Wang, S.-C. (2005). What drives mobile commerce?: An empirical evaluation of the revised technology acceptance model. Information \& management, 42(5), 719-729.

Yu, C.-S. (2012). Factors affecting individuals to adopt mobile banking: Empirical evidence from the UTAUT model. Journal of Electronic Commerce Research, 13(2), 104.

Zhou, T., Lu, Y., \& Wang, B. (2010). Integrating TTF and UTAUT to explain mobile banking user adoption. Computers in Human Behavior, 26(4), 760-767. doi: 10.1016/j.chb.2010.01.013 